\title{
'Just the gun is scary'
}

In his 29 years with the Fiji Times, chief photographer Asaeli Lave has survived death, disappointment, criticism and blame. But there have been many exciting moments.

\section{By ASHWINI PRABHA}

HE SURFS the region with his camera. Be it moments of anguish or ecstasy, Asaeli Lave has captured them all. Entering his office you see gadgets ranging from the 1980 s to the 21 st century. He speaks of bulky old Mamiya cameras to the latest digital beauty.

A light and hearty chat with him reveals more about crises that have engulfed the Pacific than reading history texts. And he has been honed by first hand experience.

Photojournalism is the unique career that has been 46-year-old Lave's life.

He has travelled the world to cover major events like the Seoul Olympics 1988 and daring ones such as the Bougainville crisis.

In his 29 years with the Fiji Times, Lave has survived death, disappointment, criticism and blame. But there have been many exciting moments.

Lucky chance: Lave was in Papua New Guinea at the time when the first peacekeeping forces were being set up in the Pacific. He admits feeling lucky at being assigned.

"We met our colleagues from the Post-Courier and were in Bougainville before our military," he says.

Some of those rebels from the Bougainville Revolutionary Army (BRA) had been in the jungle for more than 10 years."

"We were so used to hotels. But we discovered that here we had to live in those old homes owned by mining companies. We had to find our own water, 


\section{INDEX}

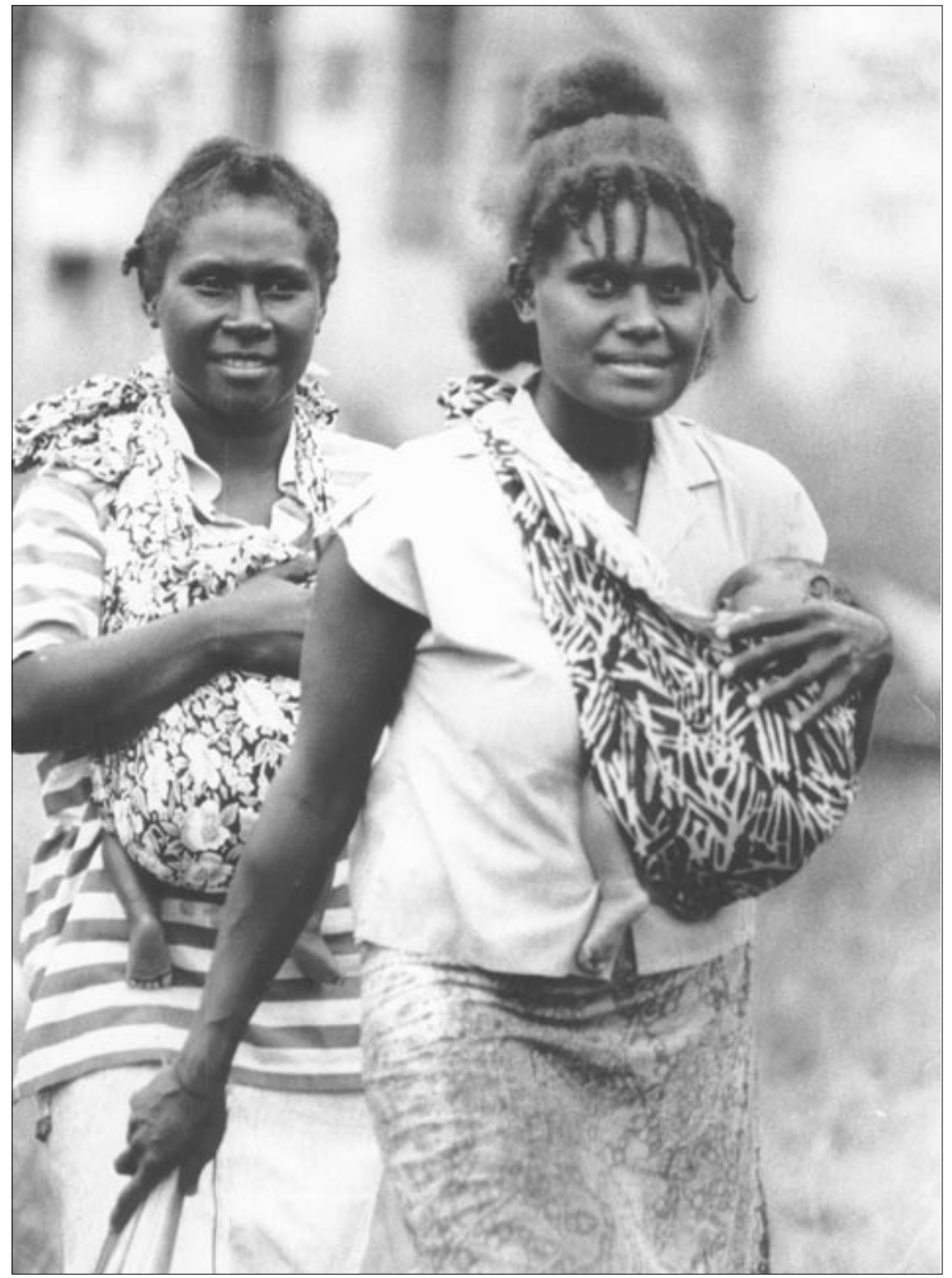

The face of conflict: This Bougainville picture of Rosa Robbins (left) and Julian Greg with their baby sons was part of a portfolio that won Asaeli Lave the Pacific Photojournalist of the year Award in 1995.

170 PACIFIC JOURNALISM REVIEW 82002 


\section{BICULTURALISM}

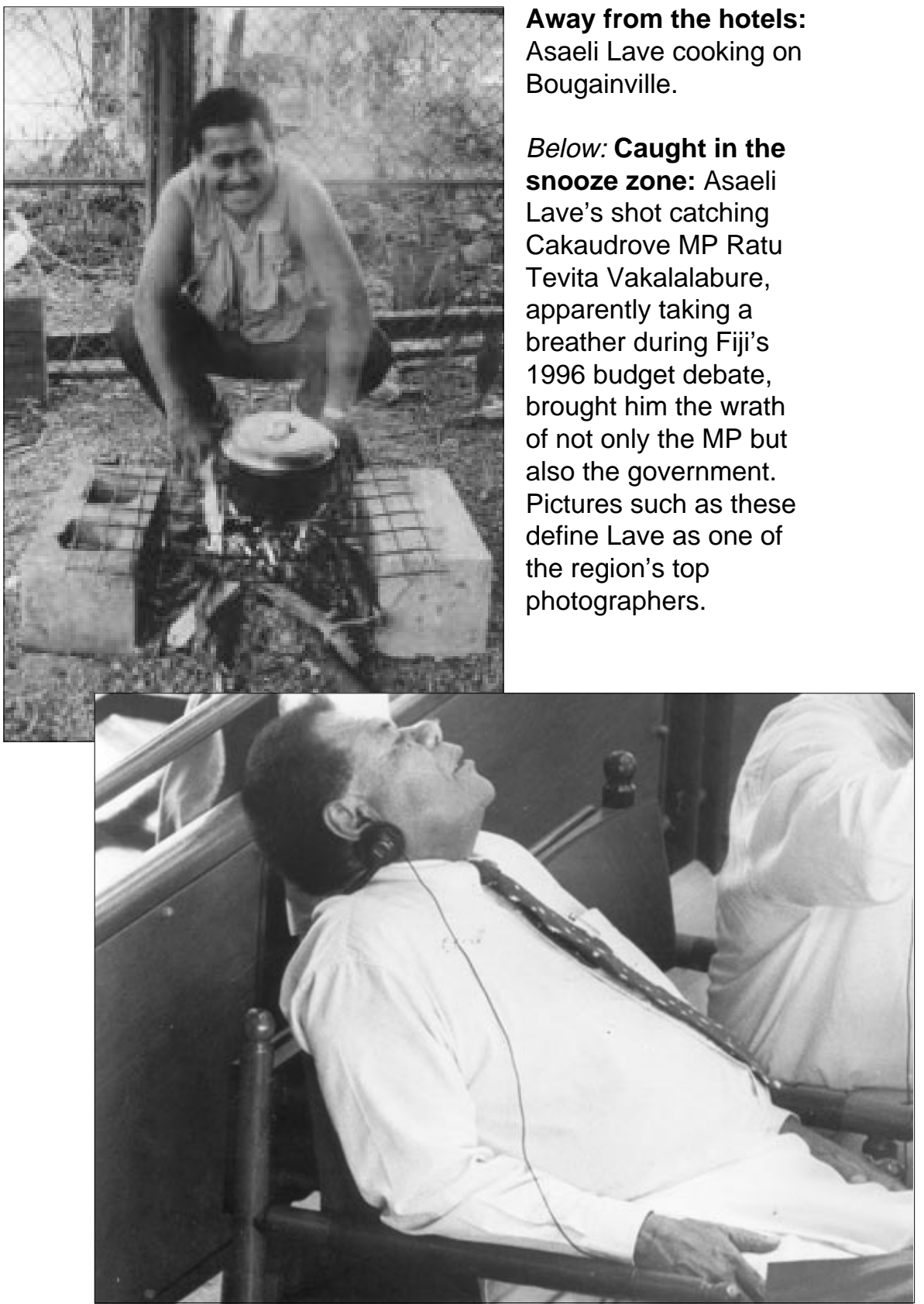

PACIFIC JOURNALISM REVIEW 82002171 


\section{INDEX}

collect old pots and get water from river. We stayed without showers for a couple of days, the only time we bathed was in the river.

"The first thing I did was to explore the place. I came to this village which was empty and walked about three to four km. I went in and shot all those pictures. Then came trouble — the soldiers said I shouldn' thave been there since I could have been shot.

"Threats are just part of the work. Fear of death is not in our mind when we look at these guys who died in Pakistan or during the coup, we just want to tell our people what's happening."

People are dying, being hurt and wounded.

The desire to get those stories and pictures and publish them for the people to see is what makes Lave tick.

"I don't know if I want to take risks but just being there, and thinking what photographs I can get, keeps me going."

His experiences during the 1987 coup brought him face to face with danger for the first time. He recalls an armed soldier storming into the Fiji Times newsroom.

"His hand was so close to the trigger, pointing at us and — to make it worse — his hands were shaking," he says.

"Two guys chased our security, kicked our door open and came in with M16s. The dangerous thing was this guy pointing his gun at me and our chiefof-staff, Mark Garrett, and his hands were shaking.

"Just the gun being pointed at you is scary.

"My friend tripped on the telephone wire and the man swore. He was furious and threatened shooting. We were told not to take anything, but leave."

However threatening it was, it turned out to be a learning time for local journalists.

At that time, the military was staging the coup and soldiers were everywhere; it affected all of Fiji. But there were no deaths.

Lave compares the two 1987 coups with the 2000 attempted coup and the aftermath when 15 people died - and says George Speight's putsch was scarier.

"In 1987, there was a march by the Methodist Church and supporters of Ratu Mara ...that was a peaceful march too. But behind the scene there were other people planning other things.

Funny thing: "The funny thing in 2000 was that this march was up to the government House and when the word came that they had taken over Parliament, the march continued on to Parliament House.

172 PACIFIC JOURNALISM REVIEW 82002 


\section{BICULTURALISM}

"And they started breaking shops.

"We were running everywhere. It was hard, we didn't know what was happening until the press conference by the rebels."

He describes the November mutiny as a time that gripped him with fear.

"The thing that had made me so scared was the mutiny. We had gone to Namadi to watch the whole thing from across the road, from where [Commander Frank] Bainimarama ran away. It was daylight — everybody ran. We were fortunate we were able to hide behind our vehicle.

"They could have killed us if they wanted to. We asked one of our vehicles to stop in front, so it could block us. In that situation our driver panicked and sped and the rest of the guys ran after the van."

"One member was lying on the ground, we thought he was dead. A sigh of relief, he was just pretending to lie down out of fear.

"I heard our front tyre being shot and because we were so scared we didn't stop - just drove. And when we stopped some 200m away, our boys were so scared they didn't even use the jack. They just lifted the vehicle and changed the tyre.

"Our driver was so silly, the rest of the guys could have been killed."

Hailing from Lau and a father of six children, Asaeli faced many hurdles growing up. When his dad died, he dropped out of school.

His first work experience was at the 1972 South Pacific Festival of Arts.

"That's the first time I ever touched a camera, they gave me a still Mamiya, big old ones with 120 film. They don't exist anymore."

While working for the festival he became closer to the Ministry of Information, his interest in photography soared from then on.

It was however in 1973 that his news photography career kicked off when he joined Fiji Times as a cadet photographer. They needed a Fijian reporter since the company travelled frequently to villages.

Lave pays tribute to those who played a part in his professional life. He trained under New Zealand photographer Chris Moorehouse - "I thought it was an experience working with people like him."

Since joining Fiji Times, he has switched careers from photojournalist to chief-of-staff and back to photography. In 1980 he was appointed chief photographer.

He questions the media on their role.

"We are criticising the reconciliation processes. What have we contributed to it? The responsibility is on us." 


\section{INDEX}

Poverty line: As former secretary of the Fiji Journalists Association, he says he feels for younger journalists and understands that wages are not attractive.

"We write about people being below the poverty line but some of our journalists are in this situation. It's the same all over the region and not only in Fiji," he says.

His colleagues describe him as a man with great personality and he certainly believes in cooperation between journalist and photographers.

"Journalists and photographers work as a team. You can't work if either one is not able to work with another. You share that story."

In the today's world, no story is complete without a picture. This is the proof.

$\square$ Ashwini Prabha is a final-year journalism degree student at the University of the South Pacific. This article was originally published in the April 2002 edition of Wansolwara, USP.

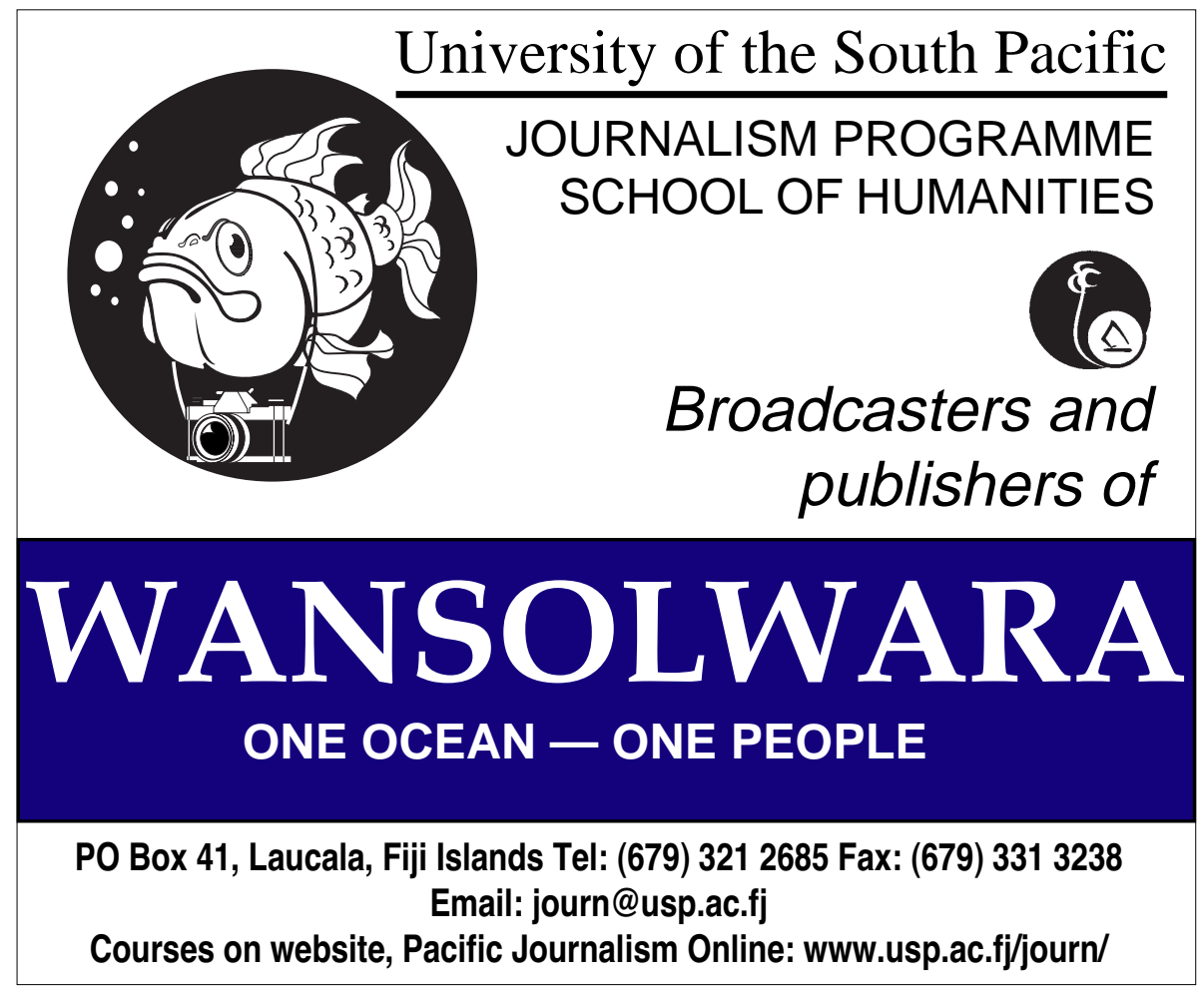

174 PACIFIC JOURNALISM REVIEW 82002 